\title{
Romanticism and New Awareness in Indonesian Literature: Lombok's Representation in Novel Opto Ergo Sum
}

\author{
Dharma Satrya HD ${ }^{1}$, Faruk $^{2}$, Pujiharto ${ }^{3}$ \\ \{. dharmasatryahd@gmail.com ${ }^{1}, \underline{\text { farukfaruk7676@gmail.com }}{ }^{2}$, pujiharto@ugm.ac.id ${ }^{3}$ \} \\ ${ }^{1}$ Universitas Hamzanwadi, Indonesia \\ ${ }^{2,3}$ Universitas Gadjah Mada, Indonesia
}

\begin{abstract}
This article discusses love in the Opto Ergo Sum novel represented as something that exists not compilation. This article applies Stuart Hall's representation theory and method and positions the novel in the context of ethnic awareness in Indonesian literature. The context which elevates Lombok's ethnicity in Indonesian literature. Lombok is constructed as an ontological Islam[1]. Krufeld constructed Islam Lombok in the concept of two, wetu telu (three times) and wetu lima (five times)[2]. Wetu lima Islam originated from Middle Eastern Islam brought back by Lombok pilgrims. In this context, Rahmat brought his love from Lombok but found new love in Cairo, where he studied Islam. Rahmat got his love by not choosing one of the two women who loved him, Auliya (Lombok) and Salma (Cairo). The novel offers a new romanticism that is different from the one found in the Balai Pustaka tradition of Indonesian literature. Romanticism in the Balai Pustaka tradition tends to be a unification of love, whereas in contemporary Indonesian literature, in the case of the Opto Ergo Sum novel, the realization of love is rejected, unrequited.
\end{abstract}

Keywords: love, representation, Islam, Indonesian Literature, unification, rejection

\section{Introduction}

The nature of choosing Lombok as a discourse, according to Fadjri, is an Islamic one [1]. Lombok has been accepted as early as Islam. Ontologically Lombok is Islam. Fadjri discovered the original Sasak creed in the Sasak secret dialect. Unlike what was said by Fadjri, Syukur, Jamaludin, Asmawi, and Budiwanti, discourse on the original Sasak religion was a boda [3] - [6]. Hoping ontologically, Lombok is worthy of Islam.

Hunter [7] sees the first "Lombok is Islam" as a modern Sasak identity and the second "Lombok is worthy of Islam" as a traditional identity. The first is a modern Sasak ontology and the second is Sasak tradition. Krulfeld saw one of the two forms of social Sasak society [2]. The social type of the community is the first as the type of society at the time of five and the second type of society at the time of three (wetu telu).

The Sasak Islamic discourse, especially Middle Eastern Islam, dominated the Sasak discourse in the 2000s. Asnawi saw that 'Tuan Guru' was present as a complement to Islamic teachings [6]. Fadli showed that the science of Sasak scholars was published from Haramain [8]. Fahrurrozi emphasized the role of 'Tuan Guru' in promoting social political change in Lombok [9]. Kingsley and Macdougall chose how 'Tuan Guru' were able to become peacekeepers in Lombok [10], [11].

The issue of Islam and 'Tuan Guru' is the main choice of novelists in ethnic discussions in contemporary Indonesian literature. The adoption of ethnic discourse in national literature became a contemporary trend in the world of literature. The studies show how ethnicity in America voiced 
its ethnic identity in national literature [12]. In the context of Indonesian literature, ethnic consciousness emerged in producing and appreciating novels. Ethnic awareness in national literature has also become a focus of reseach among Indonesian literary academics [13] - [23].

This ethnic awareness also gave birth to the novels about Lombok. The novel Guru Dane raises the challenge of the uncertainty of the Sasak people in determining the role of anutan [24]. The novel Merpati Kembar addresses preserving Sasak values and culture, especially the culture of elopement [25], [26]. The novel Perempuan Rusuk Dua is a story drawing on the tradition of the smell of nyale [27]. The Tuan Guru novel is a novel that originates from the results of observations and interactions of writers with the teacher's environment [28]. The 'Tuan Guru" was constructed as an ordinary human and arranged it as a ruler to be dismantled [28], [29]. Sri Rinjani's novel constructs an image of educated Sasak women [30]. The novel Saat Cinta Tak Mau Kembali discusses community stratification based on the inheritance of nobility and through economic means [31]. Satrya sees the novel as a change in Lombok's representation [32].

The representation of Lombok in contemporary Indonesian literature is constructed in three discourses, namely traditional, modern, postmodern. Badrin [24] and Wijaya [25] are influenced by traditional discourse in representing Lombok. Zuhairini [26], Hidayatullah [27], Faozan [28], Akbar [29], Sukmawati [30] and Alaini [31] are influenced by modern discourse in representing Lombok. Satrya [32] was influenced by postmodern discourse in representing Lombok.

Lombok's representation in contemporary Indonesian novels in the case of the novel When Love Doesn't Want to Go uses romanticism as a resistance to feudalism and capitalism [32]. Romanticism itself is seen as a a form of resistance to modernism [33]. The romanticism offered by Opto Ergo Sum [34] differs from Indonesian literary romanticism found in Balai Pustaka novels and contemporary Indonesian literature. Romance in the Balai Pustaka novels tends to try to unite even if the effort is unsuccessful [35]. Romanticism in the novel Opto Ergo Sum consciously avoids unification. This is the difference in romanticism in Indonesian literature in the Balai Pustaka tradition with the romance of contemporary Indonesian novels including the Lombok case.

\section{Methodology}

This article uses Stuart Hall's model representation theory. The representation theory approves two discussions, namely discussing semiotics and discourse. Semiotic techniques are used to find meanings in novels, while an analysis of discourse is used to find sources of meaning. Semiotic data and discourse is obtained from the literature. The meaning of the Opto Ergo Sum novel is analyzed semiotically. In analyzing the novel, Lombok about Lombok learns the importance of determining the meaning of the novel. In this case, the experience as a Lombok person determines the interpretation of the meaning of the novel. The novel Opto Ergo Sum is assumed to have a constructed meaning of Lombok. This meaning is processed through language [36]. Ontologically, language is a sign and an ideological language. In exchanging the meaning of Lombok in the Opto Ergo Sum novel, the position of the Lombok people is very important in determining the meaning. In discourse analysis, meaning is related to knowledge that is dominant in a certain period. In this discourse analysis scientific articles or books about Lombok are used as data sources. Analysis of meaning and discourse is carried out to find the relationship between meaning and discourse whether or not in a representation regime. Data analysis is presented using the results of discourse analysis 
first from the results of semiotic analysis, because discourse increases the meaning of meaning constructed in the novel.

\section{Finding and Discussion}

\section{Lombok Islamic Discourse}

There is a religious relationship between Lombok and the Middle East. Lombok Ulama gained knowledge from Cairo. Lombok Ulama gained religious knowledge in Cairo, especially the new generation of scholars, while the old or old generation of scholars gained knowledge in Haramain. Lombok Ulama practice the teachings of Islam brought from Haramain since the 18th and 19th centuries [4]. Sasak scholars studied Islam to Haramain since the 17th and early 18th centuries [8]. The Sasak scholars studying in Haramain were the TGH Umar Buntimbe, TGH Mustafa sekarbela, TGH Abdul Ghafur, TGH Amin Sesela, TGH Mukhtar Sedayu Kediri, TGH Umar Kelayu [8]. The propagation of the master alumni teachers Haramain until the 1990s did not cause problems. The master graduates of Haramain established many Islamic boarding schools and later were handed over to their children and grandchildren. In the 2000s, the socio-religious conditions in Lombok experienced many problems under the leadership of TGH Zainul Majdi, the Governor of West Nusa Tenggara 2008-2018. The problem identified in January 2007 was the issue of identity. The Sasak community strengthens Islam as a single identity. This continued until the governor's direct election. In order to assert Islamic identity, the local government banned Ahmadiyah settlers coming to Lombok. Whatever is not part of the Middle Eastern Islamic tradition is prohibited. The tradition of gambling of Balinese people in Cakranegara gets operational permission difficulties. Why is the implementation of Islamic teachings under the leadership of TGH Zainul Majdi (also known as Tuan Guru Bajang) different from earlier practices of Islam?

Before 2000, 'Tuan Guru' were part of the political movement, while after the 2000s the teacher and politician were masters. Tuan Guru Bajang as governor and at the same time the scholars tried to apply the Islamic teachings he received from Cairo's Al-Azhar University. Tuan Guru Bajang is a graduate of Qur'anic interpretation from the oldest and largest Islamic university in the world. As a person from the region and at the same time as a cleric, Tuan Guru Bajang made his knowledge of Islam, which he obtained in Cairo, as a source of his political policy. Tuan Guru Bajang managed to increase the number of tourists coming to Lombok. The slogan "in Lombok there is Bali" apparently managed to attract many tourists. However, when he was elected as governor, he banned Bali's cock fighting tradition. This issue is not included in the Endless TBG Effort book [37].Cairo's position in the structure of religious education in Lombok reached its peak since Tuan Guru Bajang was able to become a fully-fledged cleric of the governor. The Tuan Guru Bajang nuclear family sent their children to Cairo. The Al-Azhar University of Cairo is the sole destination for masterteacher teachers from Lombok. This shows the shift from Mecca to Egypt. Guru Bajang's grandfather, who is now a national hero, studied religion in Mecca. Tuan Guru Bajang tends to choose Cairo as a place to gain the knowledge of Qur'anic interpretation.

\section{Rahmat Love: Between Lombok and Cairo}


Rahmat loves two women. First, he loved Auliya. Second, he loves Salma. Love is the first love of Lombok, while the second love is love for Cairo. The first is the mind that grows over time and their meeting process by mail, while the second is love at first sight.

While in Egypt, Rahmat often sent photos and letters. Auliya could only see his portrait from the photos sent each month. Over time, love grew in their hears. Auliya began to feel a romantic attachment. It was unclear what made her like Rahmat. Whether it was because of Rachmat's goodness or his skill in singing love poetry. I don't know for certain. That is love. It can't be measured by logic. But in my thinking I guessed, Auliya liked Rahmat because of his ability to touch Auliya's emotions. Besides that, my mother and Auliya's mother also agreed they would make relations closer then continuing to a more serious step, marriage. [34, p. 3]

Rahmat was indeed very close to that woman. Her name was Salma. A university student in the Hadits wa Ulumul Hadits Department. She had just started her second year at the Al-Azhar campus in the Nasr City district. Her figure indeed cannot be understated. An appropriate match for Rahmat's good looks. A fine-shaped nose, medium eye brows, curled eyelashes, yellowish white skin, a body like the reincarnation of a Spanish guitar, and slender and lithesome making Rahmat truly fall for her.

Rahmat had met a long time ago. At the time coinciding with a joint opening of the Indonesian University Students and Students Organisation (PPMI), Egypt. But, some time ago meeting again at the Indonesian Embassy. Since that very time, he began to make approaches to Salma. Communication between them went smoothly. Both of them exchanging telephone numbers. Even sometimes meeting by chance near the Khan Khalili market, after Salma had met with her house friends in Husein district. Rahmat began to tire of keeping a long distance relationship. His reason was simple: they had never met even once. It was become the reason why he sent another letter recently.

His hostel friends knew he was becoming close to Salma. It seemed clear when Rahmat often received calls. Since then, Rachmat never wrote letters again to Auliya. Also he did not answer my mother's letters. Even though if my mother wrote a letter, it was certain to be answered directly. But his attitudes and habits had now changed. After two months of being close to Salma, the stirring in Rachmat's soul become stronger. He then emboldened himself to say how he felt in a letter. In the space of two weeks, Salma gave an answer on her heart's desire. They then at last officially became a couple. One of the main reasons Salma accepted his love was Rachmat's seriousness in wanting to marry her. In his letter, Rahmat expressed his conviction of overflowing love. And the hopes he wished to make true in the future.

Rahmat feeling to Auliya needs enough time to love each other. The process to bond their love is by sending letters, photos, and romantic poems. While his love for Salma accidentally happens in a meeting of the event open with PPMI. How are the two love defended and chosen? Both choices are born from the problem of distance in love. Ideal love is close love, which can be held and touched not limited by geographical distance. Rahmat's feeling to Auliya is limited by distance, between Indonesia and Cairo. This distance makes Rahmat bored with his first love, Auliya. Love for Salma is love that is not distant, because Salma is in Cairo. That is, Rahmat and Salma can meet in person. The experience of love is both real. Rahmat can see the full existence of Salma. Rahmat maintains a direct relationship without letter and photo mediation. Rahmat ignores love that is distant, indirect, distant. However, is love for Salma unhindered? Love is faced by friendship. Do you choose love or friend? Rahmat's friends did not agree with his decision to leave Auliya and establish a relationship with Salma. The disagreement arises from the principle of a man who in this sense is 
firmness and commitment. Rahmat did not dare to act decisively by stating to Auliya that he was no longer in love or bored with long-distance love. Friends of Grace did not want to see Auliya injured, because the decision was taken unilaterally.

"It's true what Robi stated. Antum, don't take unilateral decisions. Grow up. If you really can't continue the relationship, please tell him. I think it's much better than playing around behind me. Your action will tarnish the good name of Auliya's family" said Hamdi.

I can no longer agree to this relationship Ham, Rob. My heart has also been made up not to inform Auliya. I will accept everything that will happen. "Rahmat replied while looking at Hamdi and Robi [34, p. 32].

\section{Ontology of Love in Novel Opto Ergo Sum: New Awareness in Indonesian Literature}

Rahmat decided not to choose both and not to listen to the advice of his friends.

Rahmat did not want to harm one of the two women who had made him in love, Auliya and Salma. Although in the deepest sense of the soul, truly loving both, his great love does not want to end with disappointment and prolonged heartache. Running and wandering as far as possible is the right choice at this time. That way, Auliya and Salma could reconstitute the soul debris he left behind scattered. Rahmat does not want to choose one of them. Because choosing one is the beginning of endless suffering. Rahmat began writing.

"Auliyaku dear"

"You know how longing and faithfulness are so strongly embedded in your soul. You really a tough woman whom I have ever met and possessed.

Thousands of sweet memories of loving you are the most beautiful gift in life. The bond of love between us is deeply rooted. However, I realize that it does not mean having to go hand in hand. Sorry, I will go far away. As far as this heart can see a ray of peace in the soul. Your faithful and sincere love will never be erased from my heart.

$* * *$

"Salma the angel of my night."

You know how much I love you. Truly you know all of this. There is no day or night as beautiful in my life except the moments I see and listen to your words of how you miss me. I know your feeling of hatred and disappointment because you know I have a sweetheart who now has opened a wide rift in this soul. But, I still love you, always and as long as I live. I will go because I don't want to hurt you and Auliya. Choosing a path to travel and roam is the best choice at this time. Each meeting certainly there is a farewell, and the situation indeed does not favour staying together. Forgive me, I have to go far away. Your name and love will remain in innermost part of my heart.

"Friend, there is no word more valuable in those we possess than sorry. Sorry for all the mistakes which have incised wounds and hatred within. For Hamdi, now you are can be free of becoming close to and loving Farha. Hopefully you will be happy. 
I will not choose Auliya or Salma, because to choose one of them is to cause the other to suffer. Going to a far away place is the best path I can choose because I do not wish to hurt two hearts.

I must go far away for a long time. Remember all the beautiful memories which be have had together. All of this I will not forget til my dying breath. I so much love you, truly. If there is still time. God will certainly bring us together."

\begin{abstract}
After morning prayers, Rahmat finished packing his goods. Only three letters remained strewn on the table. He then left the room when his hostel friends were reading the Al-Quran. Placing a letter on the study table. Whereas for Auliya and Salma it would be sent by post. He left the hostel calmly. While walking slowly he traced the cold of the Cairo streets.

Forgive me friend, you know this is a difficult path of which there is nothing in my memory. But, now my heart has chosen a way so as not to hurt anyone. I have chosen to go because by doing so, I feel what is, I feel I have love. Loving you both, loving Auliya and Salma [34, pp. 183-185]
\end{abstract}

The above quote shows how Rahmat makes the decision. Rahmat decided to leave Auliya, Salma, and his best friend because he did not want to hurt or hurt anyone. Choosing one, between Auliya and Salma is the beginning of suffering, because choosing one then hurts the other. Rahmat choses to leave, leaving everything behind. Rahmat last statement confirms the position of his choice. He felt there was only if he left. If he does not leave, he is not there. What is the relationship "there" and "leave" and why does he feel if he is gone. If he doesn't leave, he is there to choose one and that choice will hurt Auliya or Salma. Rahmat is the subject who makes the choice. The choice is directed at Salma. Rahmat's letter shows that he actually choses Salma. However, if he chooses Salma, his friend will criticize him for his choice. That is, there are two parties who will be hurt, Auliya and his best friend. If he chooses Auliya he denies his love for Salma. If he leaves, he leaves a trail. So the concept in Opto Ergo Sum novel is the concept of trace. The concept of love or having love in the novel is the concept of trace. Rahmat felt he had the love of Auliya, Salma, and his Friends when he did not want to educate everyone and choose to leave. "I go then I am" is something is a trace. That is, ontologically the existence of something is a trace. Love in the sense of Rahmat is a trace. Thus ideal love is a trace. Whole love will never be achieved. Then Rahmat has never experienced unification. Rahmat will never be able to unite with Auliya and Salma. If he chooses to unite with one of them, he is not there.

The concept of love is a form of romanticism in Indonesian literature. The romanticism in Indonesian literature Balai Pustaka is attracted to one pole to carry out unification [35], while in Opto Ergo Sum does not try to do unification. In contrast, Opto Ergo Sum rejects the unification with full awareness. Opto Ergo Sum positions love as the ideal one and does not try to be realized. The position of love in Opto Ergo Sum tends to be strong in the ideal world than in the real world.

\title{
4. Conclusion
}

Islam that developed in Lombok is Islam originated from the Middle East. The Lombok Ulama is studying religion to Haramaian. The subsequent development of the Lombok ulama, who was also the governor of Lombok, took two periods of study to Cairo's Al-Azhar University. Both are central to Islamic studies and both can complement each other. In the reform era, Lombok scholars tend to choose to study in Cairo rather than to Haramaian. Such a position is the basis for Opto Ergo Sum novel which places Rahmat, a student from Lombok, studying religion in Cairo. Rahmat found love at first sight in Cairo, Salma. Love at first glance shifts the love that has long been maintained with Auliya. The relationship with the choice of first love does not go well because 
Grace is not supported by her friends. Rahmat decides not to choose both, because he does not want to hurt or hurt both of them. Rahmat decides to leave, leaving Salma, Auliya and his best friend. Rahmat feels he has love when he doesn't have both. Grace feels there if she leaves. The ontology of love in the Opto Ergo Sum novel is a trace, because it exists when it goes away. Because he left, only traces were left behind. Love is a joke. Rahmat consciously chooses not to unite, to choose not to have one of them. This is the difference in love in the romanticism of modern Indonesian literature from contemporary Indonesian literature. Love in the novel Balai Pustaka tends to do unification. In contemporary Indonesian novels with the Lombok case, unification tends to be rejected. This is what is called new awareness in contemporary Indonesian literary novels in Opto Ergo Sum novel. That conclusion is certainly not final. That is, it needs to be tested with cases of ethnic Indonesian novels other than Lombok.

\section{Acknowledgment}

This article is part of my dissertation; therefore, I would like to express my great gratitude to the Directorate of Research and Community Service, Directorate General of Strengthening for Research and Development, the Ministry of Research, Technology and Higher Education who has funded this dissertation research.

\section{Bibliography}

[1] M. Fadjri, "Mentalitas dan Ideologi dalam Tradisi Historigrafi Sasak Lombok pada Abad XIX-XX," Universitas Gadjah Mada, 2015.

[2] R. Krulfeld, "Fatalism in Indonesia : A Comparison of Socio-Religious Types on Lombok," Anthropol. Q., vol. 39, no. 3, pp. 180-190, 1966.

[3] A. A. Syakur, Islam dan Kebudayaan: Akulturasi Nilai-Nilai Islam dalam Budaya Sasak. Yogyakarta: Adab Press Fak. Adab UIN Sunan Kalijaga Yogyakarta, 2006.

[4] Jamaludin, Sejarah Sosial Islam di Lombok tahun 1740-1935 (Studi Kasus terhadap Tuan Guru). 2011.

[5] E. Budiwanti, Islam Sasak: Waktu Telu versus Waktu Lima. Yogyakarta: LKIS, 2000.

[6] Asnawi, "Respons Kultural Masyarakat Sasak terhadap Islam,” Ulumuna, vol. IX, no. 1, pp. 1-19, 2005.

[7] C. L. Hunter, "Local Issues and Changes : The Post-New Order Situation in Rural Lombok," Sojourn J. Soc. Issue Southeast Asia, vol. 19, no. 1, pp. 100-122, 2004.

[8] A. Fadli, "Intelektualisme Pesantren: Studi Genealogi dan Jaringan Keilmuan Tuan Guru di Lombok," El Hakim, vol. 9 Nomor 2, pp. 287-310, 2016.

[9] Fahrurrozi, “Tuan Guru and Social Change in Lombok, Indonesia,” Indones. Malay World, vol. 0, no. 0, pp. 1-18, 2018.

[10] J. Kingsley, "Pelopor Perdamaian atau Perusak Perdamaian?: Pemilihan Kepala Daerah, Kepemimpinan Agama, dan Proses Perdamaian di Lombok," in Kegalauan Identitas: Agama, Etnisitas, dan Kewarganegaraan Pada Masa Pasca-Orde Baru, A. F. Susanto, Ed. Jakarta: Gramedia, 2011, pp. 97-118. 
[11] J. M. Macdougall, "Criminality and the Political Economy of Security in Lombok," in Renegotiating Boundaries, H. S. Nordholt and G. van Klinken, Eds. Brill, 2007, pp. 281304.

[12] J. Sesnic, From Shadow to Presence: Representation of Ethnicity in Contemporary American Literature. New York: Rodopi, 2007.

[13] Soedjijiono, "Menuju Teori Sastra Indonesia: Membangun Teori prosa Fiksi berbasis Novel-Novel Kearifan Lokal,” Atavisme, vol. 12, no. 1, pp. 47-63, 2009.

[14] N. N. Subardini, "Stratifikasi Masyarakat Bali dalam 'Tarian Bumi’ dan 'Kenang' karya Oka Rusmini," Balai Bahasa, pp. 214-227, 2011.

[15] I. N. D. Putra, "Eksistensi Puisi Indonesia di Bali pada Era Kolonial,” Aksara, vol. 29, no. 2, pp. 171-182, 2017.

[16] Suroso, "Kepriyayian Tokoh dalam Novel Warna Lokal Jawa dan Sumbangannya dalam Pengembangan Karakter Bangsa,” Litera, vol. 10, no. 2, pp. 183-191, 2011.

[17] Wildan, "Kearifan Lokal Dalam Novel Seulusoh Karya D. Kemalawati," Bhs. dan Seni, vol. 41, no. 1, pp. 30-39, 2013.

[18] H. Suwignyo, "Makna Kearifan Budaya Jawa dalam Puisi Pariksit, Telinga, Dongeng Sebelum Tidur, dan Asmaradana,” Bhs. dan Seni, vol. 41, no. 2, pp. 181-190, 2013.

[19] P. R. Hardiningtyas, "Manusia dan Budaya Jawa dalam Roman Bumi Manusia: Eksistensialisme Pemikiran Jean Paul Sartre,” Aksara, vol. 27, no. 1, pp. 83-98, 2015.

[20] T. Wijanarti, "Representasi Perempuan Bergelar Nyai dalam Cerita Rakyat Kalimantan Tengah," Aksara, vol. 27, no. 2, pp. 207-215, 2015.

[21] M. D. Kurnia, "Warna Lokal Melayu pada Novel Ayah Karya Andrea Hirata,” Deiksis, pp. $141-163,2015$

[22] N. Q. hadi Putri, “Kritik Sosial Suku Dayak Benuaq dalam Novel 'Api Awan Asap' karya Korrie Layun Rampan,” Bahastra, vol. 35, no. 2, pp. 65-73, 2016.

[23] Kuswarsantyo, T. Haryono, and R. M. Soedarsono, "Perkembangan Penyajian Jathilan di Daerah Istimewa Yogyakarta,” Resital, vol. 11, no. 1, pp. 15-25, 2010.

[24] Badrin, "Potret Perjuangan Tokoh Utama dan Nilai Didik dalam Novel Tuan Guru Dane karya Salman Faris serta Relevansinya dengan Pembelajaran Sastra di MA," Universitas Mataram, 2013.

[25] H. Wijaya, "Merpati Kembar di Lombok karya Nuriadi (Kajian Sosiologi Sastra, Budaya, Resepsi, dan Nilai Pendidikan)," Universitas Sebelas Maret, 2013.

[26] S. Zuhairini, "Idealisme Perjuangan Perempuan Sasak dalam Merpati Kembar di Lombok karya Nuriadi dan Relevansinya terhadap Pembelajaran Sastra di SMAN 1 Kediri Lombok Barat," Universitas Mataram, 2013.

[27] M. Hidayatullah, "Citra Perempuan Sasak dalam Novel Perempuan Rusuk Dua karya Salman Faris dan Eva Nourma (Kajian Sosiologi Sastra, Gender, Nilai Pendidikan dan 
Relevansinya dengan pembelajaran Sastra di SMA),” 2016.

[28] Faozan, "Motivasi Tindakan Salman Faris dalam Membangun Diskursus Karisma Tuan Guru dalam Novel Tuan Guru," Haluan Sastra Budaya, vol. 1, no. 1, pp. 20-40, 2017.

[29] S. Akbar, "Kajian Sosiologi Sastra dan Nilai Pendidikan dalam Novel Tuan Guru karya Salman Faris," Universitas Sebelas Maret, 2012.

[30] L. Sukmawati, B. Sudardi, and D. Susanto, "Perempuan Sasak dalam Novel Sri Rinjani karya Eva Nourma: Kajian Feminisme," Haluan Sastra Budaya, vol. 1, no. 2, pp. $177-$ $190,2017$.

[31] N. N. Alaini, "Stratifikasi Sosial Masyarakat Sasak dalam Novel Ketika Cinta Tak Mau Pergi karya Nhadira Khalid," Kandai, vol. 11 nomor 1, pp. 110-123, 2015.

[32] D. Satrya, "Feudalism versus Capitalism: The Changing Representation of Lombok in Nadira Khalid's Novel Ketika Cinta Tak Mau Pergi," 3 L Lang. Linguist. Lit., vol. 24, no. 4, pp. 115-127, 2018.

[33] Faruk, Perlawanan Tak Kunjung Usai. Yogyakarta: Pustaka Pelajar, 1995.

[34] L. Karseta, Opto Ergo Sum. Bukit Tinggi: Ajrie Publisher, 2017.

[35] Faruk, Novel Indonesia, Kolonialisme dan Ideologi Emansipatori, Kedua. Yogyakarta: Ombak, 2012.

[36] S. Hall, "The Work of Representation," in Representation: Cultural Representations and Signifying Practices, S. Hall, Ed. London: Sage Publication, 1997, pp. 1-74.

[37] A. Rosidi and F. Tolomundu, Eds., Ikhtiar Tiada Henti: Kisah Sukses TGB Membangun Nusa Tenggara barat. 2018. 